ANADOLU, J. of AARI

ISSN: 1300-0225 (Print)

E-ISSN: 2667-6087 (Online)

2021, 31 (2): 194-201

DOI: $10.18615 /$ anadolu. 1031934

\title{
Has Contract Farming Increased the Resilience of Farms in the COVID-19 Pandemic? A Case Study from Turkey
}

\author{
Nilgün DOĞAN ${ }^{I^{*}}$ \\ Hakan ADANACIOGLU ${ }^{2}$ \\ ${ }^{1}$ Gumushane University, Aydın Doğan Vocational School, Kelkit, Gümüşhane/TURKEY \\ ${ }^{2}$ Ege University, Department of Agricultural Economics, Izmir/TURKEY \\ ${ }^{l}$ https://orcid.org/0000-0002-7142-8296 $\quad{ }^{2}$ https://orcid.org/0000-0002-8439-8524 \\ *Corresponding author (Sorumlu yazar): nilgundogan@gumushane.edu.tr \\ Received (Geliş tarihi): 02.09.2021 Accepted (Kabul tarihi): 11.10.2021
}

\begin{abstract}
This paper examines the impacts of the COVID-19 pandemic on contract farming (CF), focussing on buckwheat producers in Gümüşhane province in rural area of Turkey. Our research group was buckwheat producers in Gümüşhane province in Turkey across Gümüşhane's three districts (Kelkit, Köse, and Şiran). According to empirical literature, CF improves livelihood alternatives and helps the economic development of rural areas. While COVID-19 affects the whole world, its impacts on CF has been a matter of curiosity. Thus, this paper starts with a definition of the phenomenon of CF, recent empirical studies and objectives. In order to understand the perceptions of the farmers engaged in contract farming in Gümüshane regarding the impact of the COVID-19 pandemic on buckwheat production and marketing, 28 perception statements were presented. This study's findings show that respondents underlined that they strongly agreed with the statements regarding the increase in the cost of agricultural inputs because of the COVID-19 pandemic. However, the COVID-19 pandemic has not had a negative impact on buckwheat farmers engaged in contract farming in many ways in the research area. There is still a need for authorities to manage effective crisis management plans and to launch resilience promoting policies like contract farming that aim at enhancing farmers' capabilities.
\end{abstract}

Keywords: COVID-19, contract farming, rural resilience, Gümüşhane, Turkey.

\section{Sözleşmeli Tarım COVID-19 Pandemisinde Üreticilerin Dayanıklılı̆̆ını Artırdı mı? Türkiye'den Uygulamalı Bir Çalışma}

ÖZ: Bu çalışma, Gümüşhane ilinde karabuğday üreticilerine odaklanarak COVID-19 pandemisinin sözleşmeli tarım üzerindeki etkilerini incelemektedir. Gümüşhane ilinin Kelkit, Köse ve Şiran ilçe köy ve beldelerinde sözleşmeli tarım ile karabuğday üretimi yapan üreticiler araştırma kapsamına alınmıştır. Yapılan literatür araştırmasına göre sözleşmeli tarım kırsal bölgelerde kalkınmayı ve çiftçilerin refah düzeyini etkileyen bir modeldir. Tüm dünyayı etkileyen COVID-19'un, üretim üzerindeki etkileri merak konusu olmuştur. Bu nedenle, bu araştırmada sözleşmeli tarım olgusunun tanımı, kapsamı ve etkisine ilişkin ampirik bir uygulamaya yer verilmiştir. Gümüş̧hane ilinde sözleşmeli tarım yapan çiftçilerin COVID-19 pandemisinin karabuğday üretimi ve pazarlaması üzerine etkisine ilişkin algılarını anlamak için 28 ifade hazırlanmıştır. Bu çalışmanın bulguları, katılımcıların COVID-19 pandemisi nedeniyle tarımsal girdilerin maliyetindeki artışa ilişkin ifadelere şiddetle katıldıklarını göstermektedir. Ancak COVID-19 salgınının, araştırma alanında sözleşmeli tarım yapan karabuğday çiftçileri üzerinde birçok yönden olumsuz bir etki yaratmadığ sözleşmeli tarım gibi çiftçilerin üretim kabiliyetlerini artırmayı amaçlayan ve üretim uygulamalarında esnekliği teşvik eden politikalara hâlâ ihtiyaç olduğu elde edilen sonuçlar arasındadır.

Anahtar kelimeler: COVID-19, sözleşmeli tarım, kırsal dayanıklılık, Gümüşhane, Türkiye. 


\section{INTRODUCTION}

Attempts to make progress in the agricultural production sector in developing economies face the additional challenge of major structural change in the world. Farmers' have been increasingly choosing to broaden their agricultural production through contract farming rather than working with traditional buyers. Farmers may enter contracts to reduce the transaction costs of accessing new markets, to reduce borrowing, to manage risk, to acquire information or to increase employment opportunities (Simmons, 2002). In addition, it is known that contract farming is beneficial to the welfare of farmers and provides easy access to market. In many developed countries, agricultural production is changing from an industry dominated by family-based, small-scale farms to one of larger farms that are more tightly aligned across the production and distribution value chain (Boehlje, 2000). Over the years, contract farming has been considered as a system that has potential for providing a way to integrate small-scale farmers in developing countries into export and processing markets (Kirsten and Sartorius, 2002).

Agriculture is a nature-dependent production system, making it is very difficult to control. It is not easy to realize standardized production due to different geographical conditions and soil structure. This disadvantage is more important for smallholders. In small-scale farms, farmers dominate production and can make whatever decisions they want. In this case, achieving a holistic dominance in agriculture production will only be possible by alienating the farmers from their own choices. In this sense contract farming, which is an industrial production model, is an important tool to ensure the dominance of capital and control in agriculture. Priority issues such as increasing productivity, product diversity, quality and power in agricultural production, ensuring adequate and reliable food supply, developing infrastructure of agricultural enterprises, providing agricultural inputs, and socio-economic development of rural life are directly related to contract farming. As mentioned above, the most important factor affecting agricultural production and reducing the farmer's control over production is natural factors. One of these factors is pandemic diseases.

Global pandemic diseases, which emerge from time to time, have a great impact on all aspects of human life (Bereir, 2020). For more than 18 months, the world has been struggling with the COVID 19 pandemic with countries taking precautions such as social distancing and selfisolation. All these measures against this dangerous pandemic disease negatively affected the major economic sectors such as agriculture, which serves as the backbone of the economies of most developing countries (Poudel et al., 2020). The pandemic has also affected trade of agricultural products due to additional border controls, lack of cargo shipments and reinforced sanitary controls (Elleby et al., 2020). Such limitations could also affect global agricultural production. Currently farming systems face a wide range of economic, environmental and institutional challenges (Meuwissen et al., 2019). As a result of the current pandemic, the most crucial factors that affect crop production and profitability are availability of inputs, harvest times and sowing dates.

Many researchers have focussed on the development of buckwheat as a potential functional food ingredient and many functional foods made from buckwheat have been put into production around the globe (Li and Zhang, 2001). According to FAOSTAT data (2019), the production quantity of buckwheat reached 785.702 tonnes in Russia, 430.166 tonnes in China, 85.020 tonnes in Ukraine. When we look at the export amounts of these countries that lead in buckwheat production, Russia comes first with 64.183 tons, followed by China with 22.633 tons and America with 18.830 tons (Anonymous, 2021c). Therefore, it can be said that buckwheat has started to take its place in international trade. On the other hand, this crop is not commercially cultivated in Turkey. According to Turkish Statistical Institute (TSI) data, 37.187,507 tons of cereal were produced in Turkey in 2020 and this amount was 35.140,067 tons in 2021. Considering buckwheat production in Turkey, there were no data in TSI for 2020, but it 
was seen that there was 1.280 tons of buckwheat produced in 2021 (Anonim, 2021d). When we examine the research area of this study, we see important developments in the Gümüşhane province regarding buckwheat. Four tons of certified buckwheat seeds with a 75 percent grant were distributed to the farmers in Kelkit and Şiran districts by Gümüşhane Provincial Directorate of Agriculture and Forestry within the scope of the Development of Buckwheat Production Project, and certified buckwheat seeds were planted on 55 hectares in the 2021 season and a 100 Turkish lira (TRY) per decare (1.000 TRY per hectare) premium will be given to the farmers in order to increase the buckwheat production (Anonim, 2021a). When test production of the buckwheat crop was successfully shown by the Provincial Directorate of Agriculture and Forestry, a buckwheat flour and bulgur factory was established by an entrepreneur in Kelkit district. According to the data obtained from the factory, approximately $30.000-35.000 \mathrm{~kg}$ buckwheat was harvested and buckwheat yield per hectare area of research, no other official data were found regarding the cultivated area or production amount.

The literature above provided vital understanding of the impacts of COVID-19 on agricultural economy. However, these studies generally examined impact of the virus on the agricultural economy. But according to our knowledge, there is no study that reflects the dynamic impacts that COVID-19 has on contract farmers who produce buckwheat. In our discussion of the COVID 19 impacts, we have a particular focus on buckwheat producers who deal with contract farming. An important question is whether these contract farming buckwheat producers have been especially affected by the pandemic because of the lockdowns in Turkey. The objective of this study was to identify farmer perceptions of the potential impacts of COVID-19 on buckwheat production and contract farming in Gümüşhane province in Turkey. The results provide these perceptions and highlight concerns about the resilience of buckwheat production, contract farming and other issues.

\section{MATERIALS and METHODS}

This research is a descriptive study and mainly based on interview data. The secondary data were collected from different reports, web sites and journals. The target group of this study was buckwheat producers engaged in contract farming from Gümüşhane province in Turkey across Gümüşhane's three districts (Kelkit, Köse, Şiran). Interviews were done in June and July 2021 with thirty buckwheat producers engaged in contract farming. Interviews with the farmers were carried out face-to-face, following the social distance rule. Due to the limited number of buckwheat farmers, the "full count" method was applied. In the research, "structured questionnaire method" was used. The information collected from the research sample were: buckwheat farmers' characteristics (age, gender, education, farming experience and contract farming experience) and farm characteristics (annual farm income, household size, farm size). Descriptive statistics, including frequencies, means and standard deviations, were used to describe the sample size in the research.

In the introductory instructions to the survey, the farmers were informed that attendance was voluntary, that the information they shared would not be linked to them and that the data would be reported in aggregate form only. In the first part of the survey, the buckwheat farmers were asked to respond to questions on their socio-economic characteristics. In the second part, in order to understand the perceptions of the farmers engaged in contract farming in Gümüşhane regarding the impact of the COVID-19 pandemic on buckwheat production and marketing, 28 perception statements were presented. A 5-point Likert scale was used to measure the perceptions of the farmers, from 1= "strongly disagree" to $5=$ "strongly agree".

\section{RESULTS and DISCUSSION}

\section{Socio-economic characteristics of buckwheat farmers engaged in contract farming}

The socio-economic characteristics of the farmers are shown in Table 1. The age range of 25-71 encompassed the majority of the farmers. The 
N. DOĞAN, H. ADANACIOGLU: HAS CONTRACT FARMING INCREASED THE RESILIENCE OF FARMS IN THE COVID-19 PANDEMIC? A CASE STUDY FROM TURKEY

average age was found to be 49.13. As Table 1 reflects, only one of the 30 farmers participating in the survey was a woman. This result shows that the crop production sector has become a maledominant sector in the growth of commercial volume. The mean of gender as a dummy variable was found to be 0.97 . This is very close to 1 , which represents men. In considering the educational status of the participants, it was seen that the education level of farmers varied between primary school and university. The average education level of the farmers was determined as 4.43 years. This corresponds to the level of education between middle school and high school. The household size of the farmers varied between 2 and 9 persons, with an average of 3.90 persons.

Another factor that is considered to be significant for agricultural production success is years of experience. The agricultural experience of the farmers varied between 2 and 50 years. The average period of agricultural experience was determined as 21 years. The contract farming experience of the farmers in buckwheat production ranged from 1 to 3 years, with an average of 1.51 years. While the average size of farm varied between 1 and 300 hectares, the average size of the farms was 26.57 hectares. Apart from buckwheat, other grain crops (einkorn wheat, triticale, barley, oats, corn, etc.) and forage crops (alfalfa, sainfoin) were grown in the research area. In addition, some farmers who are in the research group grew potatoes and lentils.

Average annual income per farmer was 75,001100.000 TRY ( $€$ 7.223.30-9.630.94). The lowest annual agricultural income was 50.001-75.000 TRY ( $€ 4,815.57-7,223.21)$ and the highest was 150.001-175.000 TRY (€ 14.446.51-16.854.15).

Table 1. Socio-economic characteristics of buckwheat farmers.

Çizelge 1. Karabuğday üreticilerinin sosyo-ekonomik özellikleri.

\begin{tabular}{|c|c|c|c|c|c|}
\hline $\begin{array}{l}\text { Characteristic } \\
\text { Özellikler }\end{array}$ & $\begin{array}{l}\text { Description } \\
\text { Tanımlama }\end{array}$ & $\begin{array}{l}\text { Min. } \\
\text { Min. }\end{array}$ & $\begin{array}{l}\text { Max. } \\
\text { Maks. }\end{array}$ & $\begin{array}{c}\text { Mean } \\
\text { Ortalama }\end{array}$ & $\begin{array}{l}\text { Std. dev. } \\
\text { St. sapma }\end{array}$ \\
\hline $\begin{array}{l}\text { Age } \\
\text { Yaş }\end{array}$ & $\begin{array}{l}\text { Average age of farmers (years) } \\
\text { Çiftçilerin ortalama yaşı }\end{array}$ & 25 & 71 & 49.13 & 12.632 \\
\hline $\begin{array}{l}\text { Gender } \\
\text { Cinsiyet }\end{array}$ & $\begin{array}{l}\text { Gender of farmers: } 0=\text { female. } 1=\text { male. } \\
\text { Kadın: } 0 \text { Erkek: } 1\end{array}$ & 0 & 1 & 0.97 & 0.183 \\
\hline $\begin{array}{l}\text { Education } \\
\text { Eğitim durumu }\end{array}$ & $\begin{array}{l}\text { Farmers' educational level: } \\
\text { 1:illiterate 2:literate 3:primary school } \\
\text { 4:secondary school 5:high school 6:university } \\
\text { Çiftçilerin Eğitim Seviyesi: } \\
\text { 1:okuma yazma bilmeyen } 2 \text { :okuma yazma } \\
\text { bilen 3:ilkokul 4:ortaokul 5:lise 6:üniversite }\end{array}$ & 3 & 6 & 4.43 & 1.223 \\
\hline $\begin{array}{l}\text { Household size } \\
\text { Hane büyüklüğü }\end{array}$ & $\begin{array}{l}\text { Average household size (people) } \\
\text { Ortalama hane büyüklüğüu (kişi) }\end{array}$ & 2 & 9 & 3.90 & 1.788 \\
\hline $\begin{array}{l}\text { Farming experience } \\
\text { Tarım deneyimi }\end{array}$ & $\begin{array}{l}\text { Farming experience of farmers } \\
\text { Çiftçilerin tarım deneyimi }\end{array}$ & 2 & 50 & 21.00 & 14.666 \\
\hline $\begin{array}{l}\text { Contract farming } \\
\text { experience } \\
\text { Sözleşmeli tarım } \\
\text { deneyimi }\end{array}$ & $\begin{array}{l}\text { Contract farming experience of farmers in } \\
\text { buckwheat production } \\
\text { Çiftçilerin karabuğday üretiminde sözleşmeli } \\
\text { tarım deneyimi }\end{array}$ & 1 & 3 & 1.51 & 0.63362 \\
\hline $\begin{array}{l}\text { Farm size } \\
\text { Arazi büyülüğü }\end{array}$ & $\begin{array}{l}\text { Average farm size (hectares) } \\
\text { Ortalama çiftlik büyüklüğü (hektar) }\end{array}$ & 1 & 300 & 26.57 & 54.748 \\
\hline $\begin{array}{l}\text { Annual farm income } \\
\text { Y1ll1k gelir }\end{array}$ & $\begin{array}{l}\text { Average annual income of farmers (TRY)*: } \\
\text { less than or equal to: } \\
\text { Çiftçilerin ortalama y1llık geliri (TL)*: daha } \\
\text { az veya eşit: } \\
\text { 1) } 50,000 \text { 2) } 50,001-75,0003) 75,001-100,000 \\
\text { 4) } 100,001-125,0005) 125,001-150,000 \\
\text { 6) } 150,001-175,0007) 175,001-200,000 \\
\text { 8) } 200,001 \text { and above/ve üzeri }\end{array}$ & 2 & 6 & 3.47 & 1.042 \\
\hline
\end{tabular}


The form of contract farming in buckwheat production

The interviewed farmers first started contract farming with buckwheat production. The transition of farmers to contract farming was realized with the direction of a firm in the province. According to the contract farming agreement between the farmers and the related firm, the firm supplies the inputs for buckwheat production. This firm also makes decisions about the use of these inputs. But, the firm's inputs to farmers are generally limited to seeds. According to the survey results, it was determined that, although very rarely, the firm supplies fertilizer to some farmers as well as seeds.

In terms of marketing of buckwheat, an agreement is made between the farmers and the firm on the price and amount to be purchased. According to contract requirements, purchase guarantee is given by the firm for all the buckwheat produced. In addition, it was also determined that a price guarantee was given to the farmers by the firm.

The buckwheat producers included in the research have an average of 1.5 years of experience in contract farming (Table 1). As can be understood from this finding, contracted buckwheat production is fairly new in the research area. The adoption of contractually grown buckwheat by farmers will play a role in increasing the number of producers.

\section{Impact of the COVID-19 pandemic on contract buckwheat farmers}

In this section, the change of buckwheat production in Gümüşhane province compared to the period before the COVID-19 pandemic was analysed with some indicators. In this context, the impact of the change in main agricultural indicators was presented for input prices, production cost, transportation of products, demand and supply, access to agricultural information and credit opportunities, agricultural income and agricultural supports. Likert scale averages of the farmers to the statements are shown in Table 2. According to these findings, the participants significantly agreed about the increase in input prices as production costs (4.17). It was found that the smallholders mostly agreed with the statements that "prices of fertilizer (4.79) and pesticide (4.67) have increased", followed by the statements about the increase in fuel (4.55) and seed prices (4.45), respectively. Respondents underlined that they strongly agreed with the statements regarding the increase in the cost of agricultural inputs because of the COVID-19 pandemic. As was noted in the study of Elleby et al. (2020), domestic markets are related to the world market through trade. Therefore, a price increase on the world market will cause an increase in the domestic price as well. The depreciation of the Turkish currency against the US dollar and the Euro during the pandemic has undoubtedly caused the prices of many imported inputs to increase.

The interviewed buckwheat producers engaged in contract farming were found to have a moderate response on buckwheat production areas and buckwheat productivity. It is possible to say that the interviewed buckwheat farmers agree, but do not strongly agree with the statement regarding buckwheat production compared to the period before the COVID-19 pandemic. However, according to the findings in Table 2, a significant majority of the participants stated that during the pandemic, they had no problem with accessing water resources, water prices or electricity costs. In the research area the farmers do not pay for water, they provide their water needs from wells. From the interviews, it was also understood that there is still a water problem for the farmers in the area, therefore, most of them use dry land for agricultural production. According to the perceptions of the participants, the COVID-19 pandemic did not pose a significant problem in terms of sowing and harvesting times, access to credit opportunities and agricultural information, supplying fertilizers and pesticides, transporting the products to the market, finding workforce and quality seed. We can say that crop production was not affected by the lockdown in the research area of this study. In contrast, Middendorf et al. (2021), 
N. DOĞAN, H. ADANACIOGLU: HAS CONTRACT FARMING INCREASED THE RESILIENCE OF FARMS IN THE COVID-19 PANDEMIC? A CASE STUDY FROM TURKEY

found that substantial majorities expressed concern that COVID-19 reduced their access to inputs for the season, reduced their ability to plant crops and reduced their ability to hire labour. A similar result was found in the study of Pan et al. (2020) who found that it was difficult for crop production material including fertilizers, seeds, pesticides and other agricultural inputs to enter villages due to the city lockdowns, whereas some farmers had difficulties in accessing markets and had to destroy their unsold production (Lioutas and Charatsari, 2021). Therefore, the financial losses were even more dramatic for some perishable agricultural products. It is conceivable that the pandemic would affect the availability of labor for harvest, even though the return of urban migrants to their rural homes may have eased this constraint (Varshney et al., 2020).

Less concern was expressed about the likely impact on the farmers' agricultural income. This finding could be due to the possibility that the Government's protective measures have been applied effectively for the agricultural season and buckwheat production does not rely heavily on the manual labor force. In the study of Jambor et al. (2020), it was stated that short time frames and the perishability of agricultural produce also put serious constraints on agricultural labour. As was stated in the study of Bereir (2020) one of the immediate priorities of agricultural extension organizations in a COVID-19 context would be to assist all farmers to adapt to pandemic impacts. According to Hai-ying and Chang-wei (2020), two issues need to be addressed regarding the impacts of COVID-19 on agriculture: one is to ensure the production and supply of agricultural products and the other is to stabilize farmers' incomes. As is known, stabilizing farmers' incomes during the pandemic, in turn affects crop production. According to our results, the interviewed farmers were found to have a moderate response on agricultural income. Apparently, the pandemic did not make any significant negative change on the interviewed farmers' agricultural income (2.72). As revealed from Table 2, the buckwheat producers significantly agreed with the proposition that they were not adversely affected by the pandemic (4.10).

Table 2. Perceptions of buckwheat farmers engaged in contract farming about COVID-19.

Çizelge 2. Sözleşmeli tarım yapan karabuğday üreticilerinin COVID-19 algıları.

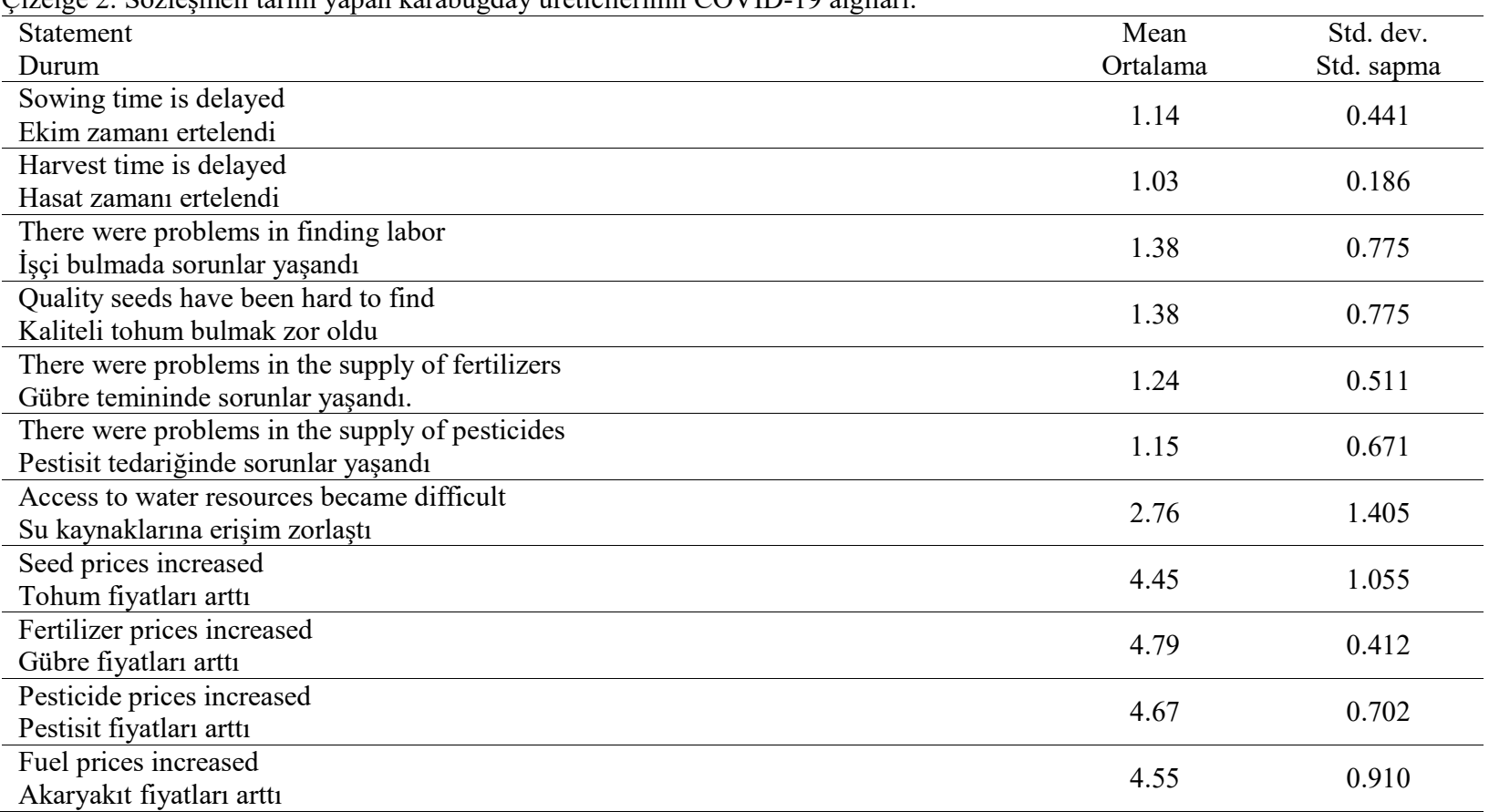


Table 2. (Continued).

Çizelge 2. (Devam).

\begin{tabular}{|c|c|c|}
\hline $\begin{array}{l}\text { Statement } \\
\text { Durum }\end{array}$ & $\begin{array}{l}\text { Mean } \\
\text { Ortalama }\end{array}$ & $\begin{array}{l}\text { Std. dev. } \\
\text { St. sapma }\end{array}$ \\
\hline $\begin{array}{l}\text { Water prices increased } \\
\text { Su fiyatları arttı }\end{array}$ & 2.24 & 1.662 \\
\hline $\begin{array}{l}\text { Electric cost increased } \\
\text { Elektrik maliyeti artt1 }\end{array}$ & 2.55 & 1.764 \\
\hline $\begin{array}{l}\text { Production cost increased } \\
\text { Üretim maliyeti artt1 }\end{array}$ & 4.17 & 1.256 \\
\hline $\begin{array}{l}\text { There were storage problems } \\
\text { Depolama sorunları vardı }\end{array}$ & 1.14 & 0.581 \\
\hline $\begin{array}{l}\text { There were problems in transporting the products to the market } \\
\text { Ürünlerin pazara ulaştırılmasında sorunlar yaşandı }\end{array}$ & 1.07 & 0.258 \\
\hline $\begin{array}{l}\text { Production demand fell } \\
\text { Üretim talebi düştü }\end{array}$ & 2.00 & 1.414 \\
\hline $\begin{array}{l}\text { Decline occurred in buckwheat supply } \\
\text { Karabuğday arzında düşüş yaşandı }\end{array}$ & 2.72 & 1.334 \\
\hline $\begin{array}{l}\text { Buckwheat prices decreased } \\
\text { Karabuğday fiyatları düştü }\end{array}$ & 1.90 & 1.145 \\
\hline $\begin{array}{l}\text { Access to credit facilities decreased } \\
\text { Kredi olanaklarına erişim azaldı }\end{array}$ & 1.45 & 0.870 \\
\hline $\begin{array}{l}\text { Producers had problems in accessing agricultural information } \\
\text { Üreticiler tarımsal bilgiye erişimde sorun yaşadı }\end{array}$ & 1.62 & 1.083 \\
\hline $\begin{array}{l}\text { Buckwheat production areas decreased } \\
\text { Karabuğday üretim alanları azald } 1\end{array}$ & 3.00 & 1.165 \\
\hline $\begin{array}{l}\text { I changed my production pattern during the pandemic period } \\
\text { Pandemi döneminde üretim şeklimi değiştirdim }\end{array}$ & 1.48 & 1.090 \\
\hline $\begin{array}{l}\text { The amount of buckwheat production decreased compared to the pre-pandemic } \\
\text { Pandemi öncesine göre karabuğday üretimi azaldı }\end{array}$ & 2.38 & 1.115 \\
\hline $\begin{array}{l}\text { Buckwheat productivity fell } \\
\text { Karabuğday verimliliği düştü }\end{array}$ & 3.10 & 0.860 \\
\hline $\begin{array}{l}\text { Agricultural subsidies were insufficient } \\
\text { Tarımsal destekler yetersizdi }\end{array}$ & 2.66 & 1.610 \\
\hline $\begin{array}{l}\text { My agricultural income decreased } \\
\text { Tarımsal gelirim azald } 1\end{array}$ & 2.72 & 1.437 \\
\hline $\begin{array}{l}\text { Contract farmers were not adversely affected by the pandemic } \\
\text { Sözlesmeli ciftciler salgından olumsuz etkilenmedi }\end{array}$ & 4.10 & 1.263 \\
\hline
\end{tabular}

Mean: mean score of likert scale (1: Strongly Disagree -5: Strongly Agree). Ortalama: Likert ölçeği puan ortalaması (1: Kesinlikle katılmıyorum, 5: Kesinlikle kat1lyorum).

\section{CONCLUSION}

In this study, based on experiences learned from the COVID-19 pandemic, we present the impacts which major pandemics have on agricultural production and discuss contract farming as a method that can help farmers overcome such crises. Although our findings show that the COVID-19 pandemic has not had a negative impact on agriculture in many ways in the research area, there is still a need for authorities to have effective crisis management plans and to launch resilience-promoting policies that aim at enhancing farmers' ability like contract farming. In terms of this study's results, the most important factor in the adoption of this production is buckwheat yield per hectares. Therefore, efforts to increase yield will play a role in bringing buckwheat, which has a purchase and price guarantee, to local production. Therefore, agricultural extension organizations should strengthen the capacities of extension officers for preparing and conducting suitable extension messages that should cover the farmers' awareness about the contract buckwheat production. The farmers in the research area should not rely on traditional agricultural production methods. Public services supporting the buckwheat producers engaged in contract farming, such as agricultural extension, and related support services such as training, coordination meetings, field visits 
could be disrupted during the pandemic. According to the findings of this study, the support received through agricultural extension organisations was enough for the smallholders in the area to continue their agricultural activities during the pandemic. Reduced human mobility normally affects sowing and harvesting processes. But in terms of the farmers, buckwheat production mostly does not rely on labor. Therefore, the pandemic conditions did not affect labor in the buckwheat production.

\section{REFERENCES}

Anonim. 2021a. Gümüşhane'de karabuğday hasadı. Gümüşhane İl Tarım ve Orman Müdürlüğü. https://gumushane.tarimorman.gov.tr/HaberArsivi.

Anonim. 2021b. Kur oranları. T.C. Merkez Bankası. https://www.tcmb.gov.tr/kurlar/ 202106/Jun_tr.html.

Anonymous. 2021c. Crop statistics data. Food and Agriculture Organization of the United Nations (FAO). http://www.fao.org./faostat/.

Anonim. 2021d. Bitkisel üretim verileri. Türkiye İstatistik Kurumu. $\quad$ http://www.data.tuik.gov.tr/Kategori/ GetKategori? $\mathrm{p}=$ tarim.

Bereir, A.M. 2020. Impact of the COVID-19 on Sudan Agriculture: the role of agricultural extension during the pandemic era. International Journal of Agricultural Science, Research and Technology in Extension Systems 10(1): 43-49.

Boehlje, M. 2000. Critical dimensions of structural change. Unpublished document, Department of Agricultural Economics. West Layafette: Purdue University.

Elleby, C., I. Perez Dominguez, M. Adenauer. 2020. Impacts of the COVID-19 pandemic on the global agricultural markets. Environmental and Resource Economics 76: 1067-1079.

Hai-ying, G., and W. Chang-wei. 2020. Impact of the COVID19 pandemic on vegetable production and countermeasures from an agricultural insurance perspective. Journal of Integrative Agriculture 19(12): 2866-2876

Jambor, A., P. Czine, and P. Balogh. 2020. Impact of the Coronavirus on agriculture: first evidence based on global newspaper. Sustainability, 12.

Kirsten, J. and, K. Sartorius. 2002. Linking agribusiness and small-scale farmers in developing countries: Is there a new role for contract farming. Development Southern Africa 19(4): 503-529.
Restrictions during the pandemic period had a significant effect on the increase in agricultural input prices and this rise increased the cost to the farmers in the research area. Thus, agricultural farm inputs should be provided for the farmers at reasonable prices.

\section{ACKNOWLEDGEMENT}

We sincerely thank all the buckwheat farmers who participated in the survey.

Li, S., and Q. H. Zhang. 2001. Advances in the development of functional foods from buckwheat. Critical Reviews in Food Science and Nutrition, 41: (6) 451-464, DOI: $10.1080 / 20014091091887$

Lioutas, E. D., and C. Charatsari. 2021. Enhancing the ability of agriculture to cope with major crises or disasters: what the experience of COVID-19 teaches us. Agricultural Systems 187.

Meuwissen, M. P. M., P. H. Feindt, A. Spiegel, C. J.A.M. Termeer, E. Mathijs, Y. Mey, et al. 2019. A framework to assess the resilience of farming systems. Agricultural Systems 176, DOI: https://doi.org/ 10.1016/j.agsy.2019.102656

Middendorf, B. J., A. Faye, G. Middendorf, Z.P. Steward, P. K. Jha, P.V.V. Prasad. 2021. Smallholder farmer perceptions about the impact of COVID-19 on agriculture and livelihoods in Senegal. Agricultural Systems 190. DOI: https://doi.org/10.1016/ j.agsy.2021.103108

Pan, D., J. Yang, G. Zhou, and F. Kong. 2020. The influence of COVID-19 on agricultural economy and emergency mitigation measures in China: A text mining analysis. Plos One, 15(10): 1-20.

Poudel, P. B., M. R. Poudel, A. Gautam, S. Phuyal, C. K. Tiwari, N. Bashyal, and S. Bashyal. 2020. COVID-19 and its impact on food and agriculture. J Biol Today's World 9(5): 221.

Simmons, P. 2002. Overview of smallholder contract farming in developing countries. FAO Document Repository. From http://www.fao.org/3/a-ae023t.pdf.

Varshney, D., R. Devesh, and J.V. Meenakshi. 2020. Impact of COVID-19 on agricultural markets: assessing the roles of commodity characteristics, disease caseload and market reforms. Indian Economic Review, 55: 83103. 